\title{
Regulation of $\mathrm{NAD}^{+}$glycohydrolase activity by $\mathrm{NAD}^{+}$-dependent auto-ADP-ribosylation
}

\author{
Myung-Kwan HAN , Ji-Young LEE ${ }^{\star} \uparrow$, Yee-Sook $\mathrm{CHO}^{\star}$, Young M. SONG*, Nyeon-Hyoung AN $\dagger$, Hyung-Rho $\mathrm{KIM}^{\star}$ \\ and Uh-Hyun $\mathrm{KIM}^{\star}+\oint$ \\ *Department of Biochemistry and IInstitute of Cardiovascular Research, Chonbuk National University Medical School, Chonju 561-182, Korea, and \\ $\dagger$ College of Pharmacy, Wonkwang University, Iksan 570-749, Korea
}

$\mathrm{NAD}^{+}$glycohydrolase (NADase; EC 3.2.2.5) is an enzyme that catalyses hydrolysis of $\mathrm{NAD}^{+}$to produce ADP-ribose and nicotinamide. Its physiological role and the regulation of its enzymic activity have not been fully elucidated. In the present study, the mechanism of self-inactivation of NADase by its substrate, $\mathrm{NAD}^{+}$, was investigated by using intact rabbit erythrocytes and purified NADase. Our results suggest that inactivation of NADase was due an auto-ADP-ribosylation reaction. ADPribosylated NADase of rabbit erythrocytes was deADP-ribosylated when incubated without $\mathrm{NAD}^{+}$, and thus enzyme activity was simultaneously restored. These findings suggest that reversible auto-ADP-ribosylation of NADase might regulate the enzyme's activity in vivo.

\section{INTRODUCTION}

$\mathrm{NAD}^{+}$glycohydrolase (NADase; EC 3.2.2.5), the enzyme that catalyses the hydrolysis of $\mathrm{NAD}^{+}$to nicotinamide and ADPribose, is present ubiquitously from bacteria to mammals [1-10]. Most eukaryotic NADases are membrane-associated and the activity of the enzyme is exclusively localized at the outer surface of the membrane [6-10]. Ecto-NADase of rabbit erythrocytes can be solubilized by treatment with a bacterial phosphatidylinositol-specific phospholipase C (PI-PLC), suggesting that NADase might be anchored to the cell membrane via glycosylphosphatidylinositol (GPI) [11]. Previously we have purified this GPI-anchored NADase with an apparent molecular mass of $65 \mathrm{kDa}$ [12]. We showed that macrophage cell lineages express high concentrations of NADase whereas other tissues express different concentrations of the enzyme $[6,13,14]$. The physiological role and the regulation of GPI-anchored NADase are still unknown.

$\mathrm{NAD}^{+}$-dependent disappearence of cellular NADase activity was first observed by Lieberman working with suspension cultures of intact mouse fibroblast cells [15]. Removal of NAD ${ }^{+}$ caused a rapid reappearance of the enzyme activity. Therefore NADase activity might be regulated by its substrate. This observation has been confirmed with NADases from various sources, although the inactivation seems to differ qualitatively between the NADases investigated [16-18]. We investigated the mechanisms involved in the inactivation of NADase because of the possible importance of $\mathrm{NAD}^{+}$-dependent inactivation of NADase in cellular regulation. We observed that the selfinactivation reaction occurred on the cell surface of intact rabbit erythrocytes and with the purified enzyme, indicating that $\mathrm{NAD}^{+}$dependent inactivation of NADase is most probably caused by auto-ADP-ribosylation. The ADP-ribosylation proceeded reversibly in intact erythrocytes.

\section{MATERIALS AND METHODS}

\section{Materials}

$\mathrm{NAD}^{+}$, ATP, ADP-ribose, $1, N^{6}$-etheno-NAD ${ }^{+}$and Cibacron Blue-agarose were obtained from Sigma Chemical Co (St. Louis, MO, U.S.A.). Omnisorb cells were purchased from Calbiochem (La Jolla, CA, U.S.A.). [adenylate $\left.{ }^{32}{ }^{2}\right] \mathrm{NAD}^{+}(1000 \mathrm{Ci} / \mathrm{mmol})$ was obtained from Amersham (Bucks., U.K.) and [adenine-2,8$\left.{ }^{3} \mathrm{H}\right] \mathrm{NAD}^{+}(4 \mathrm{Ci} / \mathrm{mmol}$ ) from Du Pont (Boston, MA, U.S.A.). PI-PLC from Bacillus cereus was purchased from BoeringerMannheim (Mannheim, Germany). Snake-venom phosphodiesterase was obtained from Worthington (Freehold, NJ, U.S.A.). Polyethyleneimine cellulose thin-layer chromatography plates were purchased from Schleicher \& Schuell (Dassel, Germany). An NADase-specific antiserum was raised by immunizing goats with purified NADase from rabbit erythrocytes, and anti(NADase $\mathrm{IgG}$ ) was purified by using a Protein G-agarose column (Genex, Gaithersburg, MD, U.S.A.).

\section{Purification of NADase from rabbit erythrocytes}

PBS-washed rabbit erythrocytes were incubated with bacterial PI-PLC in PBS for $30 \mathrm{~min}$ as described previously [12]. The supernatant was applied to a column of Cibacron Blue-agarose. NADase was eluted with $0.5 \mathrm{M} \mathrm{KCl}$. The purity was determined by SDS/PAGE.

\section{Preparation of immunoprecipitates of purified NADase}

Purified NADase $(100 \mu \mathrm{g})$ from rabbit erythrocytes and anti(NADase IgG) $(100 \mu \mathrm{g})$ were incubated at $4{ }^{\circ} \mathrm{C}$ for $1 \mathrm{~h}$ in Dulbecco's PBS containing $2 \mathrm{mM}$ ATP and $2 \mathrm{mM}$ ADP-ribose

Abbreviations used: GPI, glycosylphosphatidylinositol; NADase, NAD glycohydrolase; PI-PLC, phosphatidylinositol-specific phospholipase C.

$\S$ To whom correspondence should be addressed at the Department of Biochemistry, Chonbuk National University Medical School, Chonju 561-182, Korea. 
(buffer A) plus $10 \%$ (v/v) glycerol. The antibody-bound NADase was treated with $50 \mu \mathrm{l}$ of $10 \%(\mathrm{w} / \mathrm{v})$ heat-inactivated Streptococcus sp. cells (Omnisorb cells) at $4{ }^{\circ} \mathrm{C}$ for $30 \mathrm{~min}$ as previously described [14]. The immunoprecipitates were washed with PBS and resuspended in $500 \mu \mathrm{l}$ of buffer A containing $10 \%(\mathrm{v} / \mathrm{v})$ glycerol.

\section{Assay of NADase activity}

NADase activity was measured by the fluorimetric method of Muller et al. [9] after preincubation with $\mathrm{NAD}^{+}$. For preincubation of intact erythrocytes with $\mathrm{NAD}^{+}$, rabbit erythrocytes $\left(5 \times 10^{5}\right.$ cells) were incubated at $37^{\circ} \mathrm{C}$ for the indicated times with various doses of $\mathrm{NAD}^{+}$in $100 \mu$ l of buffer A, and the cells were washed with PBS. For preincubation of purified NADase with $\mathrm{NAD}^{+}, 10 \mu \mathrm{l}$ of immunoprecipitate of purified NADase was incubated at $37^{\circ} \mathrm{C}$ with various concentrations of $\mathrm{NAD}^{+}$for the indicated times in buffer A containing $10 \%$ glycerol and the precipitate of purified NADase was washed with PBS. The preincubated cells or the immunoprecipitates of purified NADase were then incubated in $50 \mu \mathrm{l}$ of PBS containing $200 \mu \mathrm{M}$ of $1, N^{6}$ etheno-NAD ${ }^{+}$. After incubation for $10 \mathrm{~min}$ at $37^{\circ} \mathrm{C}$, the reaction was stopped with $50 \mu 1$ of $10 \%$ trichloroacetic acid. The reaction mixture was centrifuged at $10000 \mathrm{~g}$ for $10 \mathrm{~min}$ and $80 \mu \mathrm{l}$ of supernatant was transferred into $0.72 \mathrm{ml}$ of $0.1 \mathrm{M}$ phosphate buffer, pH 7.4. Fluorescence was measured with a fluorimeter (Hitachi F-3010) with excitation at $297 \mathrm{~nm}$ and emission at $412 \mathrm{~nm}$. NADase activity was expressed as $\mathrm{pmol} / \mathrm{min}$ per $10^{6}$ cells.

\section{Identification of ADP-ribosylated NADase by electrophoresis}

For purified NADase, NADase-bound Omnisorb cells were incubated with $15 \mu \mathrm{M}$ [adenylate $-^{32} \mathrm{P}^{2} \mathrm{NAD}^{+}$in buffer $\mathrm{A}$ for the indicated times; NADase-bound immunoprecipitates were washed with buffer A, extracted with SDS sample buffer and analysed by SDS/PAGE by the method of Laemmli [19], followed by autoradiography. For rabbit erythrocytes, the cells were incubated with $15 \mu \mathrm{M}$ [adenylate ${ }^{32}{ }^{2}$ ] NAD ${ }^{+}$in buffer $\mathrm{A}$ for the indicated times, washed with buffer $\mathrm{A}$ and resuspended in lysis buffer $[1 \%$ (w/v) Triton X-100, $150 \mathrm{mM} \mathrm{NaCl}, 10 \mathrm{mM}$ Tris $/ \mathrm{HCl}$, $\mathrm{pH} 7.4,1 \mathrm{mM}$ EDTA, $0.2 \mathrm{mM}$ PMSF, $0.5 \%$ Nonidet P40, $2 \mathrm{mM}$ ATP, $2 \mathrm{mM}$ ADP-ribose]. After unlysed materials had been removed by centrifugation $(600 \mathrm{~g}$ for $10 \mathrm{~min})$, the supernatants were precleared with Omnisorb cells. The cleared lysates were incubated with anti-(NADase $\mathrm{IgG}$ ) for $4 \mathrm{~h}$ at $4{ }^{\circ} \mathrm{C}$ and were further incubated with Omnisorb cells for $30 \mathrm{~min}$. Immunoprecipitates were washed with lysis buffer, extracted with Laemmli buffer, and analysed by electrophoresis on $10 \%(\mathrm{w} / \mathrm{v})$ polyacrylamide gels followed by autoradiography.

\section{Identification of ADP-ribosylated amino acid residue of NADase}

After $1 \mu \mathrm{g}$ of purified NADase had been incubated with $15 \mu \mathrm{M}$ $\left[\right.$ adenylate $\left.{ }^{32} \mathrm{P}\right] \mathrm{NAD}^{+}$in buffer $\mathrm{A}$ for $1 \mathrm{~h}$, the $\left[{ }^{32} \mathrm{P}\right] \mathrm{ADP}-$ ribosylated NADase was subjected to SDS/PAGE, and then the separated protein was transferred to a poly(vinylidene difluoride) filter. The filters were incubated with water, $10 \mathrm{mM} \mathrm{HgCl}_{2}, 1 \mathrm{M}$ neutralized $\mathrm{NH}_{2} \mathrm{OH}$ or $1 \mathrm{M} \mathrm{NaOH}$ at $45^{\circ} \mathrm{C}$ for $3 \mathrm{~h}$ and then subjected to autoradiography.

\section{Analysis of products released from ADP-ribosylated NADase of rabbit erythrocytes}

After erythrocytes had been incubated with $15 \mu \mathrm{M}$ [adenylate$\left.{ }^{32} \mathrm{P}\right] \mathrm{NAD}^{+}$in buffer $\mathrm{A}$ for the indicated times, the cells were washed with buffer A. Subsequently, ADP-ribosylated erythrocytes were incubated in the absence of $\mathrm{NAD}^{+}$, the media were collected, and the concentrates of the media were applied to polyethyleneimine-cellulose TLC plates. The mixture of [adenylate $\left.-{ }^{32} \mathrm{P}\right] \mathrm{NAD}{ }^{+}$, [adenylate- $\left.{ }^{32} \mathrm{P}\right] \mathrm{ADP}-$ ribose and $\left[{ }^{32} \mathrm{P}\right] \mathrm{AMP}$ was used as standard markers and spotted on to the origin of one lane as described [20]. The samples were resolved with $0.05 \mathrm{M}$ ammonium bicarbonate as a developing solvent, and the plates were dried and autoradiographed.

\section{RESULTS}

\section{Effects of $\mathrm{NAD}^{+}$on NADase activity of intact rabbit erythrocytes}

To study the effect of the substrate $\mathrm{NAD}^{+}$on NADase activity of rabbit erythrocytes, cells were incubated with $100 \mu \mathrm{M} \mathrm{NAD}^{+}$ for various periods or with various concentrations of $\mathrm{NAD}^{+}$for $80 \mathrm{~min}$ at $37^{\circ} \mathrm{C}$. The time course of inactivation of NADase is shown in Figure 1. In the absence of $\mathrm{NAD}^{+}$, NADase activity did not change when incubated at $37^{\circ} \mathrm{C}$ for up to $80 \mathrm{~min}$. However,

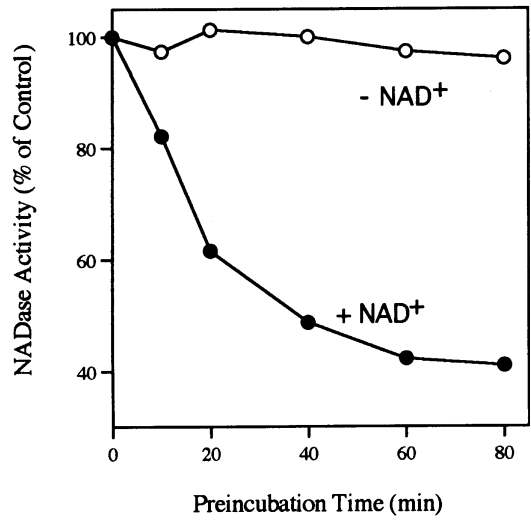

Figure 1 Effect of preincubation of rabbit erythrocytes with NAD

Erythrocytes $\left(5 \times 10^{5}\right.$ cells) were incubated with or without $100 \mu \mathrm{M} \mathrm{NAD}^{+}$for various lengths of time at $37^{\circ} \mathrm{C}$ and then washed with PBS. NADase activity was assayed as described in the Materials and methods section.

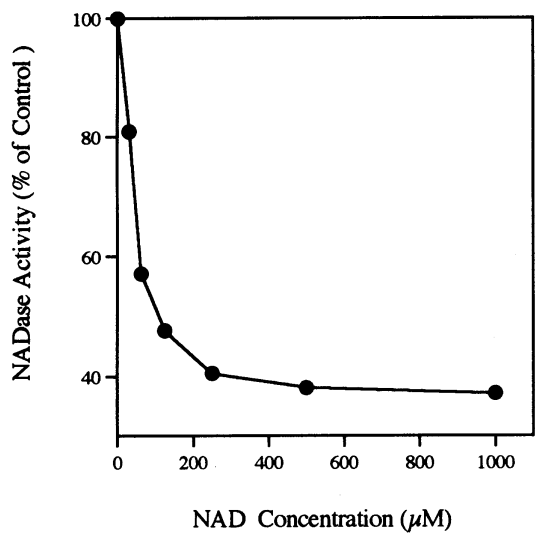

Figure 2 Effect of preincubation of rabbit erythrocytes with various amounts of $\mathrm{NAD}^{+}$

Erythrocytes $\left(5 \times 10^{5}\right.$ cells) were incubated with various concentrations of $\mathrm{NAD}^{+}$for $40 \mathrm{~min}$ at $37^{\circ} \mathrm{C}$ and then washed with PBS. NADase activity was assayed as described in the Materials and methods section. 


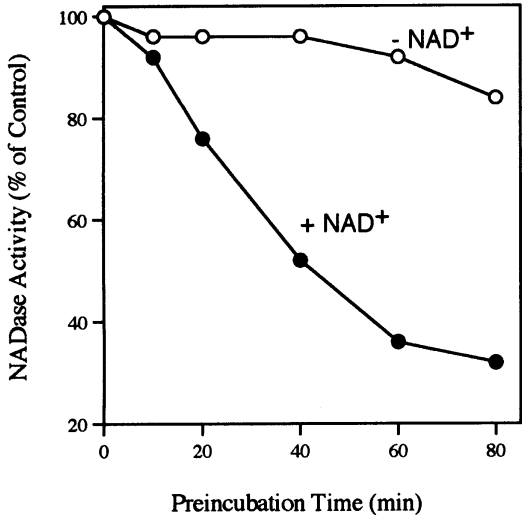

Figure 3 Effect of preincubation of purified NADase with NAD

Purified NADase was immunoprecipitated with anti-(NADase $\lg G$ ) as described in the Materials and methods section. The immunoprecipitate was incubated with or without $100 \mu \mathrm{M} \mathrm{NAD}$ for various lengths of time at $37^{\circ} \mathrm{C}$ and then washed with PBS. NADase activity was assayed as described in the Materials and methods section.

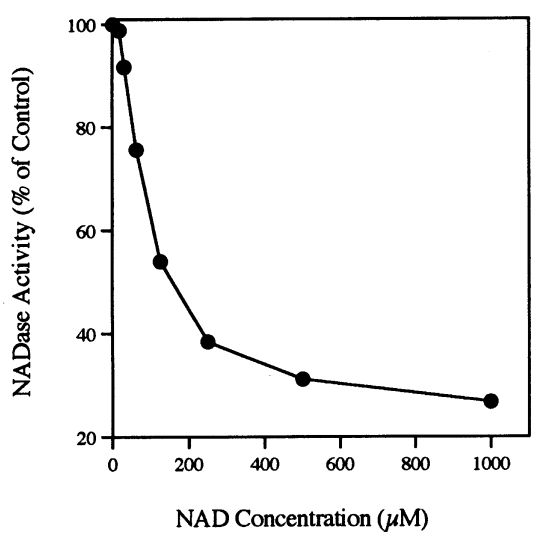

Figure 4 Effect of preincubation of purified NADase with various amounts of $\mathrm{NAD}^{+}$

Purified NADase was immunoprecipitated with anti-(NADase $\lg G$ ) as described in the Materials and methods section. The immunoprecipitate was incubated with various concentrations of $\mathrm{NAD}^{+}$at $37^{\circ} \mathrm{C}$ for $40 \mathrm{~min}$ and then washed with PBS. NADase activity was assayed as described in the Materials and methods section.

as shown in Figure 1, preincubation with $\mathrm{NAD}^{+}$decreased the enzymic activity by more than $60 \%$ at the end of the $80 \mathrm{~min}$ reaction. The concentration-dependent decrease in NADase with an $\mathrm{IC}_{50}$ of $105 \mu \mathrm{M}$ is shown in Figure 2. The above results suggest that NADase is inactivated by its substrate NAD ${ }^{+}$.

\section{Effects of $\mathrm{NAD}^{+}$on purified NADase activity}

To determine whether purified NADase is also inactivated by $\mathrm{NAD}^{+}$, purified NADase from rabbit erythrocytes was incubated with $100 \mu \mathrm{M} \mathrm{NAD}{ }^{+}$for various periods or with various concentrations of $\mathrm{NAD}^{+}$for $80 \mathrm{~min}$. As with the NADase activity of erythrocytes, the purified enzyme was also inhibited by $\mathrm{NAD}^{+}$in time-dependent (Figure 3) and concentration-dependent manners with an $\mathrm{IC}_{50}$ of $165 \mu \mathrm{M}$ (Figure 4).

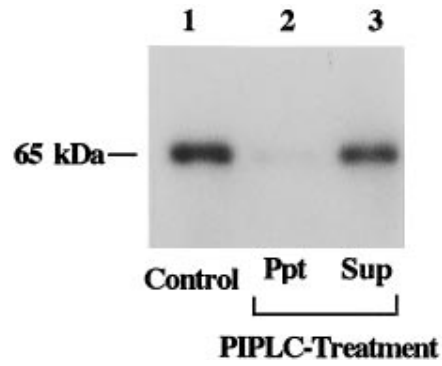

Figure 5 Radiolabelling of $65 \mathrm{kDa}$ NADase by [adenylate- $\left.{ }^{32} \mathrm{P}\right] \mathrm{NAD}^{+}$in rabbit erythrocytes

Erythrocytes $\left(10^{6}\right.$ cells) were incubated with [adenylate $\left.{ }^{32} \mathrm{P}\right] \mathrm{NAD}^{+}$for $1 \mathrm{~h}$ and an aliquot of the cells was lysed in lysis buffer (lane 1). The resuspended cells were further incubated with $10 \mathrm{ng}$ of PI-PLC at $37^{\circ} \mathrm{C}$ for 20 min and the reaction mixture was separated from the cells by rapid centrifugation ( $600 \boldsymbol{g}$ for $10 \mathrm{~min}$ ). The pellet was lysed in lysis buffer (lane 2). The supernatantcontaining reaction mixture (lane 3) and lysates were immunoprecipitated with anti-(NADase $\lg G$ ) and subjected to SDS/PAGE as described in the Materials and methods section.

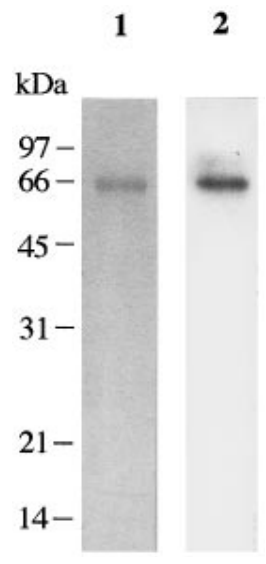

Figure 6 Purified NADase from rabbit erythrocytes and auto-ADPribosylation of the purified enzyme

NADase was purified to homogeneity and the purified enzyme was incubated with [adenylate${ }^{32}$ PJNAD ${ }^{+}$as described in the Materials and methods section. The protein was separated by SDS/PAGE and revealed with Coomassie Blue (lane 1). Subsequently, the gel was dried and autoradiographed (lane 2).

\section{NAD-dependent modification of a $65 \mathrm{kDa}$ protein in rabbit erythrocytes}

When rabbit erythrocytes were incubated with [adenylate$\left.{ }^{32} \mathrm{P}\right] \mathrm{NAD}{ }^{+}$, immunoprecipitated with anti-(NADase $\left.\mathrm{IgG}\right)$ and then analysed by SDS/PAGE, a radiolabelled $65 \mathrm{kDa}$ protein was observed (Figure 5, lane 1). When the cells were treated with PI-PLC and immediately centrifuged at $600 \mathrm{~g}$ for $10 \mathrm{~min}$, most of the radiolabelled protein was recovered from the supernatant (Figure 5, lanes 2 and 3). These results indicated that the $65 \mathrm{kDa}$ GPI-anchored protein was modified by $\mathrm{NAD}^{+}$in rabbit erythrocytes.

\section{Auto-ADP-ribosylation of NADase}

NADase was purified to homogeneity, and the purified enzyme was incubated with $\left[\right.$ adenylate $\left.{ }^{32} \mathrm{P}\right] \mathrm{NAD}^{+}$. The protein was separated by SDS/PAGE and revealed with Coomassie Blue (Figure 6, lane 1). The gel was dried and autoradiographed (Figure 6, lane 2). The purified enzyme was radiolabelled possibly because 


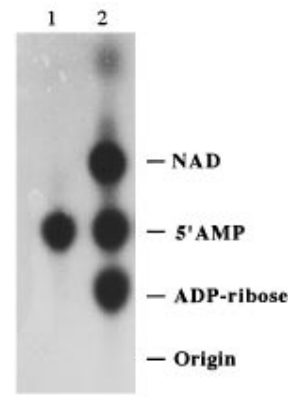

Figure 7 Release of $\left[{ }^{32} \mathrm{P}\right] A M P$ by treatment of $\left[{ }^{32} \mathrm{P}\right] A D P$-ribosylated NADase with snake venom phosphodiesterase

Purified NADase $(10 \mu \mathrm{g})$ was incubated with $15 \mu \mathrm{M}$ [adenylate $\left.{ }^{32} \mathrm{P}\right] N A D^{+}$at $37^{\circ} \mathrm{C}$ for $1 \mathrm{~h}$ and precipitated with $10 \%$ (w/v) trichloroacetic acid. After centrifugation (10000 $\boldsymbol{g}$ for $10 \mathrm{~min}$ ), the precipitate was washed with $4 \%$ trichloroacetic acid and dissolved in $10 \mu \mathrm{l}$ of $0.2 \mathrm{M} \mathrm{Tris} / \mathrm{HCl}$, $\mathrm{pH}$ 9.0. The sample was further incubated with $0.1 \mathrm{unit} / \mathrm{ml}$ snake venom phosphodiesterase in the presence of $6 \mathrm{mM} \mathrm{MgCl}$ at $37^{\circ} \mathrm{C}$ for $30 \mathrm{~min}$. The reaction mixture $(5 \mu \mathrm{l})$ was applied to polyethyleneimine-cellulose TLC plates and developed with $0.05 \mathrm{M}$ ammonium bicarbonate. After development, the plates were dried and autoradiographed as described in the Materials and methods section. Lane 1, assay; lane 2, standard markers.

of its auto-ADP-ribosylation. To examine whether the radioactivity of the $\left[\right.$ adenylate $\left.{ }^{32}{ }^{2} \mathrm{P}\right] \mathrm{NAD}^{+}$incorporated into NADase was due to ADP-ribosylation, the radiolabelled NADase was treated with snake venom phosphodiesterase, and radioactive materials released were analysed by TLC. As shown in Figure 7, the major material was identified as $\left[5^{\prime}-{ }^{32} \mathrm{P}\right] \mathrm{AMP}$, suggesting that the NAD ${ }^{+}$-dependent modification of NADase was due to monoADP-ribosylation. The possibility that the auto-ADP-ribosylation of NADase was due to non-enzymic association of ADPribose seems unlikely because the labelling reactions used in these experiments were performed in the presence of $2 \mathrm{mM}$ ADPribose. Furthermore NADase was not significantly labelled when $\left[{ }^{32} \mathrm{P}\right] \mathrm{NAD}$ was replaced with $\left[{ }^{32} \mathrm{P}\right] \mathrm{ADP}$-ribose, and NADase was not inactivated by incubation with ADP-ribose (results not shown). Auto-ADP-ribosylation of NADase may be due to covalent trapping of $\mathrm{NAD}^{+}$in the active site of the enzyme during catalysis. The finding that an excess of unlabelled NAD ${ }^{+}$ did not reduce a significant amount of radioactivity from the $\left[{ }^{32} \mathrm{P}\right]$ ADP-ribosylated NADase ruled out this possibility (results not shown). These results suggest that the nature of auto-ADPribosylation process of NADase might be due to enzymecatalysed covalent modification.

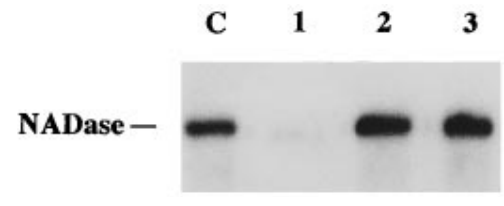

Figure 8 Treatment of [ $\left.{ }^{32} \mathrm{P}\right] A D P$-ribosylated NADase with $\mathrm{HgCl}_{2}, \mathrm{NH}_{2} \mathrm{OH}$ or $\mathrm{NaOH}$

[32P]ADP-ribosylated NADase was subjected to SDS/PAGE, after which the separated protein was transferred to a poly(vinylidene difluoride) filter. Filters were incubated with water (lane $\mathrm{C}$ ), $10 \mathrm{mM} \mathrm{HgCl}$ (lane 1), $1 \mathrm{M}$ neutralized $\mathrm{NH}_{2} \mathrm{OH}$ (lane 2), or $1 \mathrm{M} \mathrm{NaOH}$ (lane 3) at $45^{\circ} \mathrm{C}$ for $3 \mathrm{~h}$, and then subjected to autoradiography.
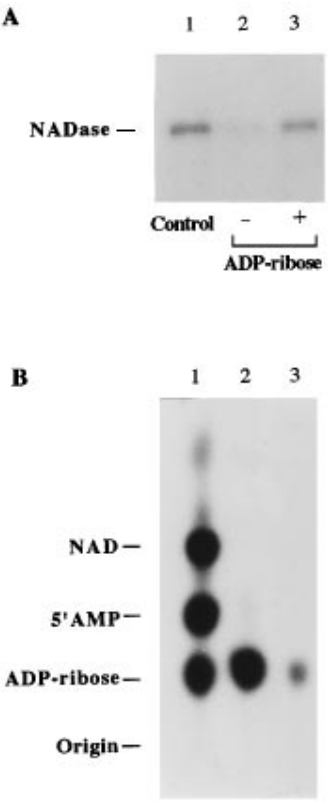

Figure 9 Release of [32P]ADP-ribose from [32P]ADP-ribosylated NADase in rabbit erythrocytes

Erythrocytes $\left(10^{6}\right.$ cells) were incubated with $15 \mu \mathrm{M}$ [adenylate- $\left.{ }^{32} \mathrm{P}\right] \mathrm{NAD}^{+}$for $1 \mathrm{~h}$ as described in Figure 5. After being washed with buffer $\mathbf{A}$, the cells were immediately lysed $(\mathbf{A}$, lane 1$)$ or further incubated at $37^{\circ} \mathrm{C}$ for $40 \mathrm{~min}$ with (A, B; lane 3) or without (A, B; lane 2) $2 \mathrm{mM} \mathrm{ADP}$ ribose in PBS. (A) The cells were lysed and then subjected to SDS/PAGE and autoradiography. (B) The reaction mixture was analysed by TLC as described in the legend to Figure 6. Lane 1 represents standard markers.

\section{Auto-ADP-ribosylation of NADase at its cysteine residue}

The presence or absence of a modified amino acid in NADase was investigated by the chemical stability of ADP-ribosyl bonds connected to amino acids. ADP-ribosylation reactions are specific for a particular amino acid residue, usually diphthamide (modified histidine), arginine or cysteine [21]. [adenylate $\left.{ }^{32} \mathrm{P}\right] \mathrm{ADP}-$ ribosylated NADase, after separation by SDS/PAGE, was transferred to a poly(vinylidene fluoride) filter, and the filter was treated with $\mathrm{HgCl}_{2}, \mathrm{NH}_{2} \mathrm{OH}$ or $\mathrm{NaOH}$. Treatment with $\mathrm{HgCl}_{2}$, which cleaves the thiol-ribose linkage, released most of the radiolabel from NADase (Figure 8, lane 1). However, the addition of $\mathrm{NH}_{2} \mathrm{OH}$ or $\mathrm{NaOH}$, which release ADP-ribose from arginine or histidine residues respectively, did not result in a significant release of ADP-ribose (Figure 8, lanes 2 and 3). Thus these results are consistent with the mono-ADP-ribosylation's occurring at a cysteine residue or cysteine residues of NADase.

\section{Reversible ADP-ribosylation of NADase in intact erythrocytes}

When the $\left[{ }^{32} \mathrm{P}\right] \mathrm{ADP}$-ribosylated cells were further incubated in the absence of [adenylate- $\left.{ }^{32} \mathrm{P}\right] \mathrm{NAD}^{+}$, there was a marked decrease in radiolabelled NADase (Figure 9A, lane 2). The lost radioactivity was mostly recovered from the incubation media as $\left[{ }^{32} \mathrm{P}\right]$ ADP-ribose (Figure 9B, lane 2). Moreover, the observed decrease in $\left[{ }^{32} \mathrm{P}\right]$ ADP-ribosylated NADase in the absence of [adenylate $\left.{ }^{32} \mathrm{P}\right] \mathrm{NAD}^{+}$was specifically inhibited by the addition of ADP-ribose to the incubation medium (Figure 9A, lane 3). There might be an enzyme on the cell surface of the erythrocytes 


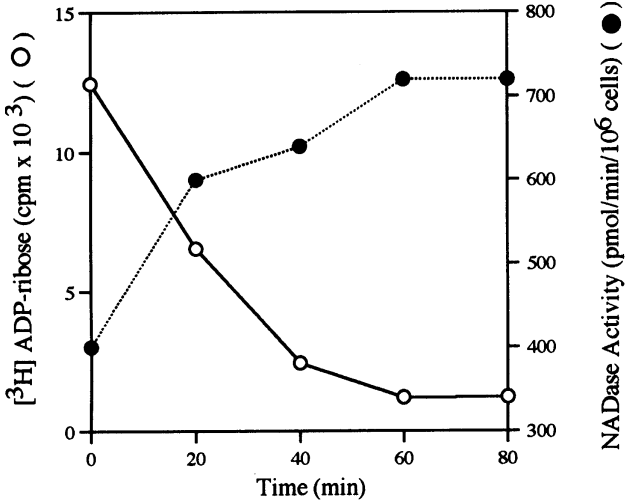

Figure 10 Correlation of de-ADP-ribosylation and recovery of NADase activity

Erythrocytes $\left(10^{6}\right.$ cells) were incubated with $100 \mu \mathrm{M}$ [adenine ${ }^{3} \mathrm{H}_{\mathrm{NAD}} \mathrm{Nat}^{+} 3{ }^{\circ} \mathrm{C}$ for $1 \mathrm{~h}$. The cells, after being washed, were incubated in the absence of $\mathrm{NAD}^{+}$. During incubation, the aliquots of the cell suspension were assayed for residual $\left.{ }^{3} \mathrm{H}\right] \mathrm{ADP}$-ribose and NADase activities as described in the Materials and methods section.

responsible for the removal of ADP-ribose from the modified NADase.

\section{Restoration of the repressed activity of NADase by de-ADP- ribosylation}

To study whether the NADase activity could be restored by deADP-ribosylation of the enzyme, erythrocyte NADases were ADP-ribosylated by being incubated with $\mathrm{NAD}^{+}$or [adenine-2,8${ }^{3} \mathrm{H}_{\mathrm{NAD}}{ }^{+}$as described above; the cells were then further incubated in the absence of $\mathrm{NAD}^{+}$. Aliquots of the cells were taken and their NADase activities and the remaining $\left[{ }^{3} \mathrm{H}\right]$ ADP-ribose were measured. NADase activities increased and $\left[{ }^{3} \mathrm{H}\right]$ ADP-ribose of NADase decreased with incubation time (Figure 10). These results suggest that the activity of ADPribosylated NADase in the erythrocytes was restored by deADP-ribosylation.

\section{DISCUSSION}

Here we present evidence that $\mathrm{NAD}^{+}$-dependent ADP-ribosylation of NADase occurred in intact erythrocytes, causing inactivation of the enzymic activity. This ADP-ribosylation was catalysed by NADase itself, because a similar finding was also observed with purified NADase. ADP-ribosylated NADases were de-ADP-ribosylated in intact rabbit erythrocytes in the absence of $\mathrm{NAD}^{+}$, and NADase activity was simultaneously restored. These results suggest that ecto-NADase in the erythrocytes might be regulated by $\mathrm{NAD}^{+}$-dependent auto-ADP-ribosylation.

We have previously measured the circulating NAD level in the plasma of human, mouse, rat and rabbit [12]. The source of this extracellular $\mathrm{NAD}^{+}$is not known, but might be from cell lysis. Extracellular $\mathrm{NAD}^{+}$would not be futilely degraded by ectoNADases without specific mechanisms to control enzymic activity. The reversible ADP-ribosylation of NADase, described here, certainly could provide one of the regulatory mechanisms of this enzymic activity. Other NADase families, such as ADPribosyl cyclase (CD38), ADP-ribosyl transferase and T lymphocyte alloantigen RT6 are also auto-ADP-ribosylated [22-24]. Because all of these enzyme molecules have their catalytic domains on the outer surface of the cells [25-27], their activities might be auto-ADP-ribosylated, preventing them from unneccessarily destroying $\mathrm{NAD}^{+}$in the extracellular space.

Reversible ADP-ribosylation of NADase was observed only in intact cells (Figure 10), not in the purified enzyme. These results suggest that de-ADP-ribosylation might be mediated by specific enzyme(s) on the cell surface of the erythrocytes. Tanuma and Endo [28] reported that ADP-ribosylcysteine hydrolase activity, which hydrolyses the linkages between ADP-ribose and the cysteine residues of inhibitory GTP-binding protein $\left(\mathrm{G}_{\mathrm{i}}\right)$, was found in the cytosol of human erythrocytes. It is quite possible that in our study there was a similar enzyme on the cell surface.

Under our experimental conditions, less than $10 \mu \mathrm{M} \mathrm{NAD}^{+}$ was not sufficient for $\mathrm{NAD}^{+}$-dependent inactivation of NADase. Thus it is conceivable that there are some regulatory cofactor(s) in the extracellular fluid that facilitate auto-ADP-ribosylation of NADase at the physiological concentration of NAD ${ }^{+}$. Because several forms of ADP-ribosylation factor are regulatory factors for various ADP-ribosylation reactions [29], it is worth pursuing whether ADP-ribosylation factors are also involved in the present auto-ADP-ribosylation of NADase.

ADP-ribosyl transferase catalyses the transfer of ADP-ribose from $\mathrm{NAD}^{+}$to an acceptor protein. In the absence of a specific acceptor protein, some ADP-ribosyl transferases can catalyse the transfer of ADP-ribose to water, representing an NADase activity. Free amino acids can also act as acceptors for ADPribose [30,31]. Because cysteine specifically blocks auto-ADPribosylation and $\mathrm{NAD}^{+}$-dependent inactivation of NADase, NADase might have a transferase activity towards free cysteine (results not shown), although further studies are needed to determine whether NADase has an intrinsic transferase activity as well.

We thank Dr. W. K. Paik at Ajou University for his critical review of our work. This research was supported by grants from the Korea Science and Engineering Foundation awarded to U.-H.K. (no. 951-0709-031-1) and from the Wonkwang University Research Foundation to N.-H.A.

\section{REFERENCES}

1 Gopinathan, K. P., Sirsi, M. and Vaidyanathan, C. S. (1964) Biochem. J. 91, 277-282

2 Anderson, B. M., Yost, D. A. and Anderson, C. D. (1986) Methods Enzymol. 122 173-178

3 Everse, K. E., Everse, J. and Simeral, L. S. (1980) Methods Enzymol. 66, 137-144

4 Williams, G. T., Ford, C. C. and Shall, S. (1962) Biochem. Biophys. Res. Commun. 108, 36-41

5 Anderson, B. M. and Yuan, J. H. (1980) Methods Enzymol. 66, 144-150

6 Han, M. K., An, N.-H. and Kim, U.-H. (1995) Biochem. Biophys. Res. Commun. 213, 730-736

7 Alivisatos, S. G. A., Kashket, S. and Denstedt, O. F. (1956) Can. J. Biochem. Physiol. 34, 46-60

8 Pekala, P. H. and Anderson, B. M. (1978) J. Biol. Chem. 253, 7453-7459

9 Muller, H. M., Muller, C. D. and Schuber, F. (1983) Biochem. J. 212, 459-464

10 De Wolf, M. J. S., Guido, A. F., Van Dessel, G., Albert, R., Lagrou, A., Herwing, J. J., Hilderson, H. J., Wilfrid, S. H. and Dierick, W. (1985) Biochem. J. 226, 415-427

11 Kim, U.-H., Rockwood, S. F., Kim, H.-R. and Daynes, R. A. (1988) Biochim. Biophys. Acta $965,76-81$

12 Kim, U.-H., Kim, M. K., Kim, J. S., Han, M. K., Park, P. H. and Kim, H.-R. (1993) Arch. Biochem. Biophys. 305, 147-152

13 Han, M. K., Kim, J.-H., Lee, D.-G. and Kim, U.-H. (1995) Histochem. Cell Biol. 104 185-189

14 Han, M. K., Yim, C.-Y., An, N.-H., Kim, H.-R. and Kim, U.-H. (1994) J. Leukocyte Biol. 56, 792-796

15 Lieberman, I. (1957) J. Biol. Chem. 225, 883-898

16 Green, S. and Dobrjansky, A. (1971) Biochemistry 10, 2496-2500

17 Pekala, P. H., Yost, D. A. and Anderson, B. M. (1980) Mol. Cell. Biochem. 31, 49-56

18 Anderson, B. M. and Yost, D. A. (1985) Chem.-Biol. Interactions 54, 159-170

19 Laemmli, U. K. (1970) Nature (London) 227, 680-685

20 Kim, U.-H., Han, M. K., Park, B.-H., Kim, H.-R. and An, N.-H. (1993) Biochim. Biophys. Acta 1178, 121-126 
21 Ueda, K. and Hayaishi, 0. (1985) Annu. Rev. Biochem. 54, 73-100

22 Grimaldi, J. C., Balasubramanian, S., Kabra, N. H., Shanafelt, A., Bazan, J. F., Zurawski, G. and Howard, M. C. (1995) J. Immunol. 155, 811-817

23 Yamada, K., Tsuchiya, M., Nishikori, Y. and Shimoyama, M. (1994) Arch. Biochem. Biophys. 308, 31-36

24 Maehama, T., Nishina, H., Hoshino, S., Kanaho, Y. and Katada, T. (1995) J. Biol. Chem. 270, 22747-22751

25 Malavasi, F., Funaro, A., Roggero, S., Horenstein, A., Calosso, L. and Mehta, K. (1994) Immunol. Today 15, 95-97
26 Moss, J., Stanley, S. J., Nitingale, M. S., Murtagh, J. J., Monaco, L., Mishima, K. Chen, H.-C., Williamson, K. C. and Tsai, S.-C. (1994) Mol. Cell. Biochem. 138 $157-166$

27 Koch, F., Haag, F., Kashan, A. and Thiele, H.-G. (1990) Proc. Natl. Acad. Sci. U.S.A. 87, 964-967

28 Tanuma, S. and Endo, H. (1990) FEBS Lett. 261, 381-384

29 Welsh, C. F., Moss, J. and Vaughan, M. (1993) J. Biol. Chem. 268, 17837-17843

30 Moss, J., Stanley, S. J. and Watkins, P. A. (1980) J. Biol. Chem. 255, 5838-5840

31 Tanuma, S., Kawashima, K. and Endo, H. (1987) J. Biochem. 101, 821-824

Received 5 March 1996/17 May 1996; accepted 29 May 1996 